\title{
A survey of scale insects (Hemiptera: Coccoidea) occurring on olives in Tunisia
}

\begin{abstract}
A survey performed in 2009 within 52 Tunisian olive groves, located in 17 different olive-growing sites, revealed the occurrence of six scale insects on olives. The identified species were: the armoured scales Aspidiotus nerii Bouché, Lepidosaphes ulmi (L.), and Parlatoria oleae (Colvée), the soft scales Saissetia oleae (Olivier) and Filippia follicularis (Targioni Tozzetti) and the mealybug species Peliococcus cycliger (Leonardi). The soft scale $F$. follicularis is a new record for the Tunisian insect fauna. Among these species, $S$. oleae was the predominant scale insect occurring throughout olive groves of northeastern Tunisia, whereas the mealybug $P$. cycliger was by far the most abundant species within olives groves of the Northwest region of Tunisia. However, P. oleae was the least abundant species, being present in only one olive-growing site in northeastern Tunisia. Larvae of the noctuid moth Eublemma scitula (Rambur) were reported feeding on S. oleae and the coccinellid Chilocorus bipustulatus L. was found feeding on both S. oleae and A. nerii. The two hymenopteran species Scutellista cyanea Motschulsky and Metaphycus spp. were recorded as the main parasitoids of S. oleae.

Riassunto - Uno studio sulle cocciniglie (Hemiptera: Coccoidea) dell'olivo in Tunisia

Una ricerca effettuata nel 2009 in 52 oliveti della Tunisia, situati in 17 località,ha rilevato la presenza di 6 specie di cocciniglie infestanti gli olivi. Si è trattato di Aspidiotus nerii Bouché, Lepidosaphes ulmi (L.), Parlatoria oleae (Colvée), Saissetia oleae (Olivier), Filippia follicularis (Targioni Tozzetti) e di Peliococcus cycliger (Leonardi. F. follicularis è un nuovo reperto per l'entomofauna della Tunisia. S. oleae è risultata predominante e presente in particolare negli oliveti del nord-est della Tunisia, mentre $P$. cycliger è stata la specie più frequente negli oliveti del nordovest. Invece, $P$. oleae è risultata la specie meno abbondante essendo presente solo in un oliveto del nord-est. Viene riferito che le larve del Nottuide Eublemma scitula (Rambur) si nutrono di S. oleae, mentre il coccinellide Chilocorus bipustulatus L. è stato osservato nutrirsi sia di S. oleae, che di Aspidiotus nerii. Gli Imenotteri Scutellista cyanea Motschulsky and Metaphycus spp. sono stati osservati come comuni parassitoidi di S. oleae.
\end{abstract}

Key words: Diaspididae, Coccidae, Pseudococcidae, Olea europaea, Tunisia. 


\section{INTRODUCTION}

The olive (Olea europaea L.), a long-lived evergreen, is a worldwide economically important horticultural crop. Most olive growing countries are localized in the Mediterranean basin which has more than $90 \%$ of the world's cultivated olive trees. Although the Mediterranean climate is suitable for olive-tree production, this last is hampered by several biotic constraints. Indeed, olive tree can often be attacked by fungi, bacteria, viruses, weeds, nematodes and insects, inducing substantial economic losses.

Several insect pests are known to cause serious damages to olives. Although the olive fruit fly, Bactrocera oleae (Gmelin), is considered to be the most important insect pest of olives worldwide (Daane \& Johnson, 2010), other groups including scale insects, could also have a negative impact on olive trees' production and productivity throughout olive-growing areas. In the Mediterranean basin about 15-20 are permanent or occasional pests on the olive tree and, of these, approximately 10 belong to the Coccoidea (scale insects) (Pellizzari, 1997). Among scale insect pests, the black scale Saissetia oleae (Olivier) (Hemiptera: Coccidae), for example, which is believed to be native to South Africa (De Lotto, 1976), is one of the most economically important species attacking olives throughout the world and especially in the Mediterranean area (Stratopoulou \& Kapatos, 1991; Velimirovic, 1994; Pellizzari, 1997; Kumral \& Kovanci, 2004; Dos Santos, 2007; Pereira et al., 2007; Longo \& Suma, 2008; Tena et al., 2008; Delrio \& Foxi, 2010). When feeding on olives (leaves and twigs), this species secrete honeydew which supports the growth of the black sooty mold fungi, hindering the photosynthetic capacity of the plant and resulting in a reduction of the tree vigor and twig dieback in the case of heavy infestations. For these reasons, appropriate regular inspections are highly required for Integrated Pest Management (IPM) issues. As such, in each olive production country, a suitable geographical and bio-ecological characterization of scale insects species occurring, in addition to $S$. oleae, on olives is strongly recommended. However, biological control of scale insects using parasitoids and predators could be useful in limiting pest's outbreaks (Rochat \& Gutierrez, 2001; Kumral \& Kovanci, 2004; Dos Santos, 2007; Longo \& Suma, 2008; Santos et al., 2009; Delrio \& Foxi, 2010). Consequently, investigations aiming to acquire further knowledge on natural enemies associated with olive scale insects is needed for suitably implementing biological control programs in olive groves.

In Tunisia, where the most commonly cultivated olive oil varieties are both Chemlali and Chetoui and the main table variety is Meski, very few studies involving surveys of scale insects attacking olive trees have been until recently carried out. The realized studies were especially focused on determining the scale insect fauna without accurate qualitative (geographical distribution) or quantitative (abundance) characterization.

The objective of the present study was to better investigate scale insects and, whenever possible, their natural enemies in Tunisian olive groves, through a field survey of the existing species with an emphasis on the assessment of their abundance (frequency) between different geographic olive-growing sites. Such a study would accordingly be a basis for implementing a suitable IPM program against these insects within Tunisian olive groves. 


\section{MATERIALS AND METHODS}

The survey of scale insects was carried out from February to July 2009, in a total of 52 olive groves belonging to 17 different sites located in the Extreme North, the Northeast (Sahel and Cap-Bon areas), the Northwest and the Center-South regions of Tunisia (Table 1). These regions are characterized by the cultivation of various olive varieties. Indeed, Trigui et al. (2008) stated that the variety Chetoui is cultivated in the North, both varieties Chemlali and Gerboui are cultivated in the Northwest, the variety Oueslati is cultivated in the Sahel area (Northeast) and both Meski and Picholine varieties are cultivated in the Cap-Bon area (Northeast). For each selected olive grove, at least ten olive trees were randomly selected and sampled. Sampling consisted of collecting 4 shoots of $20 \mathrm{~cm}$ length and 10 leaves in each of the four directions (North, West, East, South) within each olive tree. In the laboratory, each collected sample was analyzed under a dissecting microscope by: a) counting the number of scale insect specimens found on either shoots or leaves; b) reporting parasitized and non parasitized specimens. Subsequently, collected specimens were stored in small vials containing alcohol $70 \%$ for slide-mounting, before their morphological identification to genus and species. Microscope slides were prepared following the method described by Williams \& Watson (1988a, b). The abundance (between-sites and between-regions) of the collected scale insect species was then determined. Parasitized (mummified) specimens were stored in

Table 1 - Geographic distribution within Tunisia of the investigated olive groves

\begin{tabular}{|l|l|c|}
\hline \multicolumn{1}{|c|}{ Geographical zone } & \multicolumn{1}{|c|}{ Olive-growing site } & $\begin{array}{c}\text { Number of prospected olive } \\
\text { groves }\end{array}$ \\
\hline Extreme North & Rafraf & 4 \\
\hline \multirow{5}{*}{ Northeast } & Takelsa & 5 \\
\cline { 2 - 3 } & Zanghou & 5 \\
\cline { 2 - 3 } & Manzel Bouzalfa & 2 \\
\cline { 2 - 3 } & Beni Khalled & 2 \\
\cline { 2 - 3 } & Bouargoub & 3 \\
\cline { 2 - 3 } & Hamma met & 4 \\
\cline { 2 - 3 } & Grombalia & 2 \\
\cline { 2 - 3 } & Korba & 2 \\
\cline { 2 - 3 } & Slimene & 4 \\
\cline { 2 - 3 } & Sidi Saïd & 3 \\
\cline { 2 - 3 } & Bouficha & 3 \\
\cline { 2 - 3 } & Nadhour & 3 \\
\hline Northwest & Le Kef & 2 \\
\cline { 2 - 3 } & Bousalem & 3 \\
\cline { 2 - 3 } & Testour & 3 \\
\hline Center-South & Regueb & \\
\hline
\end{tabular}


plastic boxes covered with a net. All stored mummified specimens were checked daily for parasitoid emergence.

\section{RESULTS AND DISCUSSION}

A total of 2080 samples were collected in the different sites. From these samples, six scale insect species were reported infesting olives in Tunisia. These species are: the armoured scales Aspidiotus nerii Bouché, Lepidosaphes ulmi (L.), and Parlatoria oleae (Colvée), the soft scales S. oleae and Filippia follicularis (Targioni Tozzetti), and the mealybug species Peliococcus cycliger (Leonardi). This is the first record of the soft scale F.follicularis in Tunisia. F. follicularis was found in 8 olive-growing sites of northeastern Tunisia and in one site of the Northwest region of Tunisia. This newly recorded soft scale was the most abundant scale insect species on olives of Sidi Saïd in the Sahel area (northeastern Tunisia) (Table 2). Overall, S. oleae was the predominant species, representing $72 \%$ of the total number of specimens collected from all the prospected olive groves, followed by the mealybug P. cycliger (9.7\%) and the Oleander scale A. nerii (9.3\%). The three other species were less abundant with P. oleae was the least observed $(<1 \%)$ on olive trees, being present in only one olive grove. Regarding the within-site distribution, there was a clear variability based on the abundance of the existing scale insect species. Indeed, in the olive groves belonging to Testour, Beni Khalled, and Le Kef sites, only one scale insect species was found, namely either the black scale S. oleae or the mealybug P. cycliger; whereas in each of all the other investigated sites, except for Nadhour (Northeast) and Regueb (Center-South) sites where scale insects were totally absent, at least two scale insect species were reported to occur on olives (Table 2). The mealybug $P$. cycliger was the most common (93\% of the collected specimens) species reported within olives groves of the Northwest region of Tunisia. In the extreme North and Northeast regions, $P$. cycliger was recorded in all investigated olive groves except those belonging to Beni Khalled and Bouargoub sites (northeastern Tunisia). In contrast, $S$. oleae was proven to be the most abundant scale insect occurring throughout olive groves of the Northeast region of Tunisia. Additionally, S. oleae appeared to be the most serious scale insect species due to its noteworthy damages (sooty mold fungi widely widespread on olive sections) observed on all infested olive trees. However, it should be noted that $S$. oleae was totally absent on olives of the Northwest region (Table 2). Longo \& Suma (2008) stated that in Italian olive groves, the most common and injurious scale insect species are the Pit scale Pollinia pollini (Costa), S. oleae, P. oleae and in restricted areas the Oystershell scale, L. ulmi. Besides, the same authors indicated that the mealybug P. cycliger and the Oleander scale A. nerii are little common and of no practical economic importance on olive. Likewise, $S$. oleae is the key pest of olives in Bursa (Turkey); Ph. oleae and P. oleae were also found, but they were not common in olive orchards (Kumral \& Kovanci, 2004). The present study provided evidence that $P$. oleae was rarely found on olive trees in Tunisia. Such a result is in total contradiction 
Table 2 - Within-site distribution of the scale insect species recorded in Tunisian olive groves

\begin{tabular}{|c|c|c|c|}
\hline $\begin{array}{c}\text { Investigated } \\
\text { olive-growing sites }\end{array}$ & $\begin{array}{l}\text { Total number } \\
\text { of samples }\end{array}$ & Identified species & $\begin{array}{c}\text { Percentage } \\
\text { of abundance/site }\end{array}$ \\
\hline Rafraf & 160 & $\begin{array}{l}\text { - S. oleae } \\
\text { - A.nerii } \\
\text { - L. ulmi } \\
\text { - P. cycliger } \\
\text { - F. follicularis }\end{array}$ & $\begin{array}{r}43 \\
27 \\
19 \\
9 \\
2\end{array}$ \\
\hline Takelsa & 200 & $\begin{array}{l}\text { - S. oleae } \\
\text { - P. cycliger } \\
\text { - A.nerii }\end{array}$ & $\begin{array}{r}85 \\
13 \\
2 \\
\end{array}$ \\
\hline Zanghou & 200 & $\begin{array}{l}\text { - S. oleae } \\
\text { - P.cycliger } \\
\text { - A.nerii }\end{array}$ & $\begin{array}{r}91 \\
8 \\
1\end{array}$ \\
\hline Manzel Bouzalfa & 80 & $\begin{array}{l}\text { - S. oleae } \\
\text { - P. cycliger } \\
\text { - A.nerii } \\
\text { - F. follicularis }\end{array}$ & $\begin{array}{r}73 \\
19 \\
4 \\
4 \\
\end{array}$ \\
\hline Beni Khalled & 80 & - S. oleae & 100 \\
\hline Bouargoub & 80 & $\begin{array}{l}\text { - S. oleae } \\
\text { - A.nerii } \\
\text { - P.oleae }\end{array}$ & $\begin{array}{r}91 \\
8 \\
1\end{array}$ \\
\hline Hammamet & 120 & $\begin{array}{l}\text { - S. oleae } \\
\text { - A.nerii } \\
\text { - F.follicularis }\end{array}$ & $\begin{array}{r}71 \\
26 \\
3 \\
\end{array}$ \\
\hline Grombalia & 160 & $\begin{array}{l}\text { - P. cycliger } \\
\text { - S. oleae } \\
\text { - F.follicularis }\end{array}$ & $\begin{array}{r}48 \\
46 \\
6\end{array}$ \\
\hline Korba & 80 & $\begin{array}{l}\text { - S. oleae } \\
\text { - P. cycliger } \\
\text { - F.follicularis } \\
\text { - A.nerii }\end{array}$ & $\begin{array}{r}74 \\
19 \\
5 \\
2\end{array}$ \\
\hline Slimene & 80 & $\begin{array}{l}\text { - S. oleae } \\
\text { - P. cycliger } \\
\text { - A.nerii } \\
\text { - F.follicularis }\end{array}$ & $\begin{array}{r}68 \\
19 \\
12 \\
1\end{array}$ \\
\hline Sidi Saïd & 160 & $\begin{array}{l}\text { - F.follicularis } \\
\text { - S. oleae } \\
\text { - P. cycliger } \\
\text { - A.nerii }\end{array}$ & $\begin{array}{r}47 \\
31 \\
21 \\
1\end{array}$ \\
\hline Bouficha & 120 & $\begin{array}{l}\text { - S. oleae } \\
\text { - P. cycliger } \\
\text { - F.follicularis } \\
\text { - A.nerii }\end{array}$ & $\begin{array}{r}74 \\
18 \\
4 \\
4 \\
\end{array}$ \\
\hline Nadhour & 120 & - & - \\
\hline Le Kef & 120 & - P.cycliger & 100 \\
\hline Bousalem & 80 & $\begin{array}{l}\text { - P. cycliger } \\
\text { - F.follicularis }\end{array}$ & $\begin{array}{l}80 \\
20 \\
\end{array}$ \\
\hline Testour & 120 & - P.cycliger & 100 \\
\hline Regueb & 120 & - & - \\
\hline
\end{tabular}


with the current situation in Algeria where P.oleae is considered to be the most redoubtable pest affecting olive trees (Biche \& Sellami, 2011). Our finding also is in contrast to the results found by Longo (1984) that in eastern Sicilian olive groves, P. oleae was widely distributed and also was among the most serious scale insect species on olives.

In the present study, it was highlighted that $S$. oleae was attacked by larvae of the moth Eublemma scitula (Rambur) (Lepidoptera: Noctuidae), however the coccinellid Chilocorus bipustulatus L. (Coleoptera: Coccinellidae) was found feeding on both $S$. oleae and A.nerii. Additionally, the two species Scutellista cyanea Motschulsky (Hymenoptera: Pteromalidae) and Metaphycus spp. (Hymenoptera: Encyrtidae) were recorded as the main parasitoids of $S$. oleae. Similarly, in the olive groves of Bursa (Turkey), $S$. cyanea and Metaphycus sp. are the main parasitoids of S. oleae, causing high mortality of black scales (Kumral \& Kovanci, 2004). In the region of Magnesia (Greece), S. oleae is mainly parasitized by Metaphycus helvolus (Compere) (Stratopoulou \& Kapatos, 1998). Moreover, Longo (1984) pointed out that in the Italian olive groves, the most common predators attacking S. oleae are the coccinellids C. bipustulatus and Exochomus quadripustulatus (L.) and the moth E. scitula, while the most common parasitoids of the black scale are the Pteromalids S. cyanea and Moranila californica (Howard), the Calcidids Metaphycus lounsbury (Howard), Diversinervus elegans Silvestri, Coccophagus lycimnia (Walker) and M. helvolus. More specifically, in Sardinian olive groves, currently M. helvolus and M. lounsburyi, introduced for the first time 30 years ago, are well established and provide biological control of black scale (Delrio \& Foxi, 2010). By contrast, Tena et al. (2008) stated that Metaphycus flavus (Howard) and Scutellista caerulea (Fonscolombe) appeared as the main parasitoids of black scale in eastern Spain, whereas $M$. helvolus and M. lounsburyi had a limited incidence. In the olive groves of Trás-os-Montes region (Portugal), four coccinellid species, C. bipustulatus, Scymnus (Scymnus) interruptus (Goeze), Scymnus (Pullus) subvillosus (Goeze) and Scymnus (Mimopullus) mediterraneus Iablokoff-Khnzorian, are the most common predators, being potential candidates of natural control agents against S. oleae (Dos Santos, 2007).

In conclusion, of great interest is that an IPM strategy in Tunisian olives groves would be developed based on the results obtained in the present study which clearly emphasized an unequal abundance and a diverse geographical distribution of the existing scale insects on olives. Thus, pest management tools will especially be targeted towards the most common species, namely the soft scale $S$. oleae (northeastern Tunisia) and the mealybug P. cycliger (northwestern Tunisia) and this should involve further knowledge on the bio-ecology of both species. As such, further studies on the auxiliary fauna associated with these insects would prove useful in decision making for sufficient pest's control. Besides, future surveys of scale insects in other important olive-growing areas such as in Sfax and in Zarzis (southern Tunisia) should be performed for refining the overall knowledge related to this group of insects on olives in Tunisia. 


\section{ACKNOWLEDGMENTS}

The Plant Protection and Crop Production representatives belonging to the CRA, CTV or CRDA (Tunisian Ministry of Agriculture and Environment), as well as the olive growers in all investigated sites are gratefully acknowledged for their valuable support and collaboration.

\section{REFERENCES}

Biche M., Sellami M., 2011 - Biology of Parlatoria oleae C (Homoptera, Diaspididae) in the area of Cap-Djenet (Algeria). - Agriculture and Biology Journal of North America. 2: 52-55.

DAANE K. M., JohnSON M.W., 2010 - Olive fruit fly: Managing an ancient pest in modern times. - Annual Review of Entomology. 55: 151-169.

De LotTo G., 1976 - On the black scales of southern Europe (Homoptera: Coccoidea: Coccidae). - Journal of the Entomological Society of South Africa. 39: 147-149.

Delrio G., FoXI C., 2010 - Current status of Saissetia oleae biological control in Sardinia (Italy). - IOBC/WPRS Bulletin. 59: 171-176.

Dos SANTOS S.A.P. 2007 - Action of predators against the black-scale, Saissetia olea (Oliv.) in Trás-os-Montes olive groves. Ph.D. thesis, Universidade de Aveiro, Portugal, 156 pp.

Kumral N.A., Kovanci B., 2004 - Population dynamics of Saissetia oleae (Oliv.) and activity of its natural enemies in olive groves in Bursa (Turkey). In: ERKILIC L., KAYDAN M.B. (eds.), Proceeding of the X International Symposium of Scale Insects Studies, Adana, Turkey: 237-247.

LONGo S., SUMA P., 2008 - The olive scales and their entomophagous in Italy. Abstracts Book of the International Symposium on Olive Tree Integrated Pest Management, Sousse, Tunisia: 37.

LONGO S., 1984 - Distribution and density of scale insects (Homoptera, Coccoidea) on olive trees in Eastern Sicily. In: CAVAlloro R., CrovetTi A. (eds.), Proceeding of the CEC/FAO/IOBC International Joint Meeting - Integrated pest control in olive groves, Pisa, Italy: 159-168.

PellizZARI G., 1997 - Olive. In: Ben-Dov Y., Hodgson C.J. (eds.), Soft scale insects: their biology, natural enemies and control - World Crop Pests, Vol. 7, Part 2, Elsevier Science B.V., the Netherlands: 217-229.

Pereira J.A., Bento A., Torres L.M., 2007 - Distribution and spatial pattern of Saissetia oleae (Olivier) on the olive tree in the northeast of Portugal. - IOBC/WPRS Bulletin. 30: 195-196.

ROCHAT J., GUTIERREZ A.P., 2001 - Weather-mediated regulation of olive scale by two parasitoids. - Journal of Animal Ecology. 70: 476-490.

SANtos S.A.P., Pereira J.A., Torres L.M., Nogueira A.J.A., 2009 - Voracity of coccinellid species on different phenological stages of the olive pest Saissetia oleae (Homoptera: Coccidae). Applied Ecology and Environmental Research. 7: 359-365.

Stratopoulou E.T., Kapatos E.T., 1991 - Population dynamics of Saissetia oleae. I. Assessments of population and mortality. - Entomologia Hellenica. 8: 53-58.

Stratopoulou E.T., Kapatos E.T., 1998 - Key factors and regulation of population of Saissetia oleae (Hom., Coccidae) on olive trees in the region of Magnesia, Greece. - Journal of Applied Entomology. 122: 501-507.

Tena A., Soto A., Garcia-marí F., 2008 - Parasitoid complex of black scale Saissetia oleae on citrus and olives: parasitoid species composition and seasonal trend. - Biocontrol. 53: 473-487. 
Trigui A., Msallem M., 2008 - Oliviers de Tunisie: Catalogue des variétés autochtones et types locaux. - Institut de l'Olivier de Tunisie. 1: 70.

Velimirovic Y., 1994 - Black scale Saissetia oleae Olivier, significant olive pest in the area of Yugoslav seaside. - Acta Horticulturae. 356: 407-410.

Williams D.J., Watson G.W., 1988a - The Scale Insects of the Tropical South Pacific Region. Part 1: The Armoured Scales (Diaspididae). CAB International Institute of Entomology, London, UK, $290 \mathrm{pp}$.

Williams D.J., Watson G.W., 1988b - The Scale Insects of the Tropical South Pacific Region, Part 2: The Mealybugs (Pseudococcidae). CAB International Institute of Entomology, London, UK, 260 pp.

Ramzi Mansour, Rim Mkaouar, Kaouthar Grissa Lebdi - Department of Plant Protection and Post-harvest Diseases, Laboratory of Entomology, National Agronomic Institute of Tunisia, 43 Charles Nicolle Avenue, 1082 Cité Mahrajène, Tunis, Tunisia.

E-mail: ramzi_mansour82@yahoo.co.uk

POMPEO SuMA, AgATINO RuSSO - Dipartimento di Gestione dei Sistemi Agroalimentari e Ambientali, Sezione Entomologia Agraria, Università degli Studi di Catania, 100 Via Santa Sofia, 95123 Catania, Italy.

E-mail: suma@unict.it

Accepted 7 September 2011 